\title{
Complexity Level in the Use of Tense and Aspect as Perceived and Experienced by Arab EFL Learners
}

\author{
Ahmed Mohammed Al-Quyadi \\ Department of English, Faculty of Education, Sana'a, Yemen \\ \& \\ Jazan University, Saudi Arabia \\ E-mail: quiadhy@gmail.com
}

Doi:10.7575/aiac.alls.v.7n.1p.135

URL: http://dx.doi.org/10.7575/aiac.alls.v.7n.1p.135
Received: $14 / 09 / 2015$

Accepted: 15/11/2015

\begin{abstract}
It has been well learnt that a large number of Arab EFL learners encounter a considerable degree of complexity in the use of tense and aspect as fundamental components of the English language. Such a degree of difficulty is perceived and experienced by those learners at their different levels of learning English starting at the primary level up to the university level. This is what has led the researcher to carry out this research with the major aim of looking into the reasons behind the failure of such learners to handle the use of tense and aspect of English in a proper manner. The sample of this research comprised a group of students studying English as an ESP course, who were on the verge of graduation in the College of Engineering, Jazan University. The research tools used were both a test and a questionnaire. The findings of the research show that those learners encounter a great deal of complexity in the use of tense and aspect. This is clarified by means of their inability to use tense and aspect in English as correct as they should. This complexity is greater in the case of the use of the aspect. The research concludes with forwarding a number of conclusions resulting from the discussion of the results; and these conclusions are followed by a number of recommendations that can be useful for teachers, curricula designers and decision makers.
\end{abstract}

Keywords: complexity, tense, aspect, present, perfect, Arab EFL learners

\section{Introduction}

The complexity encountered by ES/FL learners in the use of tense and aspect in English has been a major subject of scientific study for a great deal of time. It is a fact that such learners have to be aware of a number of certain rules regarding the use of tense and aspect. Not only this, but complexities sometimes appear as a result of badly presented and/ or inadequate learning materials, improper teaching methods, unsuitable learning environments, and low motivation on the part of the learner, all of which make the task of learning and using such an area complex and challenging to EFL learners like those included in this study. This is so at the time when it is well known that grammar can never be separated from learning a language, whether as a first, second, third or foreign one in the sense that grammar is "a central area of the language around which other areas such as pronunciation and vocabulary revolve, (Cook, 2001: 19)." (Telda and Desta (20114: 92) add that "Grammar has been an inseparable part of language pedagogy for ages."

\subsection{Statement of the Problem}

The use of tense and aspect is one of the challenges that EFL learners, among whom Arab learners are, have to face. Such learners get confused when they have to use the correct tense (present \& past) and aspect (progressive \& perfective), as this becomes very clear when they are required to produce sentences of their own.

\subsection{Questions of the Research}

This research poses the following questions:

1. How common are the errors made by Arab EFL learners, as represented by the students of this research, in the use of tense and aspect, and which grammatical category, i.e., tense or aspect is more complex?

2. Why do EFL learners find it complex to use tense and aspect in English correctly?

3. Does the task (isolated sentences vs. a paragraph) affect the performance of the students in the use of tense and aspect?

4. What are the possible suggestions that can be helpful to solve such a problem?

\subsection{Significance of the Research}

This research has a twofold significance. On one hand, its results can help the educational authorities to think of plans ahead that can be of practical use for decision makers to take action plans so that such a complexity can be gradually minimized. On the other hand, it can help curricula designers and developers tailor the curricula according to the needs of the learners who are supposed to receive all kinds of aid and help so as to facilitate their learning of grammar rules 
and solving any difficulty that may arise as a result of their learning of such grammar rules. In much detail, curricula designers and developers can benefit in reshaping the learning materials by means of the feedback they get from what teachers report to them as the latter ones are in a direct contact with learners in classrooms.

\subsection{Objectives of the Research}

This research is meant to:

1. Find out the reasons that make it complex for EFL learners, like those included in this study, to use tense and aspect correctly.

2. Assess those learners' knowledge in both tense and aspect for the purpose of being able to decide which area is more complex than the other.

3. Help the people concerned be aware of such complexities so that they can take suitable actions.

\subsection{Limitations of the Study}

This research is limited to the two points discussed in the research being the tense and aspect. In terms of tense, it is limited to the present and past simple tenses; and in terms of aspect, it is limited to the present progressive and/ or continuous, the past progressive and/ or continuous aspects in addition to the present and past perfect aspects. It is also limited to the two skills of reading and writing due to the fact that such skills are highly demanded by learners like those in order to fulfil their academic requirements by means of reading and writing. However, errors in the use of tense and aspect while listening and speaking can go unnoticed, so they are not of a considerable significance.

\section{Review of Literature}

Undoubtedly, the knowledge of the grammar rules is essential for a language learner learning a second or a foreign language so that he/ she learns the language accurately in form and meaning (Rutherford \& SharwoodSmith (1988), Celce-Murcia (1991), Ebsworth \& Schweers (1997), Doughty \& Williams (1998), Thornbury (1999). This is due to the fact that the use of language is governed by grammar, as viewed by Al-Fallay (1998), Jdetawy (2011) and Basaeed (2013). In this regard, Hedge (2000: 143) ascertains that "Recent years have seen a resurgence of interest in the role of grammar in English language teaching." Thakur (1987: 2) points out that it is grammar, which differentiates languages "No two languages have identical conventions; if their conventions were identical in all their details, they would not be two languages."

It is highlighted that EFL learners should receive more attention on how to figure out the rules that govern the English language, particularly those related to tense and aspect (Celce-Murcia: 1991, Harmer: 1997, Al-Mutawa and Kailani: 1998, Nunan: 1999, Broughton et al: 2003, and Gebhard:2009). Meantime, it is natural, when learning, that learners usually make errors so teachers are required to look into their learners' errors as systematic attempts in order to learn. In the view of Norrish (1983), Brown (1994), Ellis (1994), James (1998) and Cook (2001) such errors are due to enable teachers know how their learners go about learning a second or a foreign language, namely English. It is also likely to make teachers realize that learning a second/ foreign language, mainly its grammar, is usually complex to EFL learners particularly Arabic speaking learners of English (Mukattash 1983, Abbad 1988, Al-Faleg 1991, Sahu 1999, Rabab'ah 2005, Basaeed 20113), who emphasize that such a complexity exists in the area of tense and aspect due to the reasons from which such errors rise as deficiency in the curriculum taught to those learners, unacceptable teaching methods and/ or techniques by some teachers, lack of a proper learning environment, and lack of motivation by a large number of learners in addition to the fact that English is learnt only as a school subject and for a very limited period of time in the classroom. Clearly, looking at learners' errors as a natural process, according to Dulay et al (1988) and James (1998), can help both teachers teach and learners learn in the way that this is likely to lead to important developments in the teaching practice.

In the view of Suleiman (1983), Oxford (1990), Dubin and Olhatain (1991), Harmer (1997), Littlewood (1992), AlQuyadi (1996), Davison and Moss (2000), and Khan (2012) analyzing errors is useful to both teachers and learners in that it tells teachers how learners learn and so teachers can go in a parallel manner of how learners progress in learning. It is further useful in the way that it establishes a link between language learning and teaching so that teachers can plan their teaching in the light of such an analysis. In summary, the researcher strongly believes that making errors is a natural part of language learning whenever and wherever it is learned. The components discussed in the topic of this research are presented as follows:

\section{- Tense}

Tense has been given a number of definitions such as a grammatical category, a grammatical device. As far as this research is concerned, it is considered as including the present simple and the past simple tenses, both of which are indicated by inflections, being marked by a third person singular- $s$ when the verb is used in the simple present, and by an $-e d$ form added to the regular verbs, and/ or a change usually in the vowel letters of the irregular verbs when such verbs are used in the simple past.

Greeenbaum and Quirk (1990: 47) state that "Tense is a grammatical category that is realized by verb inflection." Yule (2000: 58) points out that "The basic tense distinction in English is marked by two forms of the verb, the past tense ( $I$ lived there then), and the present tense (I live here at the present)." The past tense form makes the situation described more remote from the situation of utterance, (Yule, 2000: 58)." Hornby (1999:78) explains that "tenses indicate whether an action, an activity, or a state is past, present, or future." It is added that "English verbs have only two simple tenses called the Simple Present and the Simple Past. Regarding the use of the simple present tense, and as clarified by 
Greenbaum and Quirk (1990: 48), the simple present can be used to refer to "a state of affairs that existed in the past, exists now, and is likely to continue to exist in the future." On the other hand, "The simple past is used to refer to a situation set at a definite time in the past (Greenbaum and Quirk;1990: 50)."

\section{- $\quad$ The Present Simple Tense}

It is used to refer to things or actions that happen regularly or permanently. It is normally used to talk about or describe facts and habits that took place in the past, take place in the present, and may continue to take place in the future. In brief, this tense "refers to general habits, customs, characteristics, or truths (DeCapua; 2008: 168)." Chalker (1992: 76) reiterates that any period that including "the present moment of speaking (whether extending into the past or the future) can be regarded as present time and use a present tense." Regarding the verbs used in the present tense, they are of two types known as stative verbs and dynamic verbs. Stative verbs include verbs such as be, have, like, sense and so on. Such verbs are normally used to refer to single unbroken states. Examples of this type can be as follows:

She is tall.

He likes vegetables

Greenbaum \& Quirk (1990: 48) add that the simple present also includes the "timeless present, which refers to eternal truth such as: Two and three make five, or to less extreme instances of timelessness such as: The British Isles have a temperate climate. With reference to the dynamic verbs such as go, make, play, walk, speak, and write, they can also be used to refer to events that repeatedly occur without limited time extension in the past, and the present. Examples of this sort can be:

Fatima makes her own dress.

They play in the park every afternoon.

\section{- $\quad$ The Simple Past Tense}

The simple past is used to describe completed past actions or events referring to a state or to an action which happened at a particular time in the past. The time when the action happened is often stated or understood. Greenbaum and Quirk (1990: 50) clarify that "The Simple Past is used to refer to a situation set at a definite time in the past." Leech and Svartvik (1984: 65) say that it "refers to a definite time in the past which may be identified by a past time adverbial in the same sentence, the preceding language context, or the context outside the language." Examples of this tense can be as follows:

The Normans invaded England in 1066.

When we were children, we used to play with our neighbor children.

\section{- Aspect}

Attempting a kind of definition of aspect, it is "a grammatical category that reflects the way in which the meaning of a verb is viewed with respect to time, (Greenbaum and Quirk, 1990: 51)" adding that "Two aspects in English are recognized: the perfect and the progressive." Swan (1987) reiterates that aspect is defined according to whether an action is happening, was happening, or whether it has or had been completed.

The progressive aspect has had different meanings such as continued action, dynamic action, and durative action. On the other hand, the perfective aspect is meant to indicate the completeness of or effect of an action. Greenbaum and Quirk (1990: 53) point to the fact that "The progressive (or 'continuous') focuses on the situation as being in progress at a particular time", explaining that "verbs with stative senses do not occur in the progressive, since there is no conception of progression in states of affairs."

Yule (2000: 63) states that aspect can be expressed grammatically "via the perfect and progressive forms of the verb." It is further explained that "The basic grammatical distinction in English aspect is marked by two forms of the verb. These are traditionally described as versions of the verb be with the present participle (verb + -ing) for the progressive as in: $I$ am eating; I was eating, and versions of have with the past participle (verb + -en/ed) for the perfect as in: I have eaten, I had eaten."

DeCapua (2008:166) points out that "There are two different aspects in English: the progressive and the perfect." He adds that "A progressive verb phrase consists of the auxiliary be in present or past tense + the present participle of the main verb, (DeCapua; 2008:166)." Regarding the perfect, he adds "The perfect aspect describes the relationship between an earlier event or action with a later event or action", pointing that a "perfect verb phrase consists of the auxiliary have in either the present or past tense + the past participle of the verb, (DeCapua; 2008: 166.)"

\section{- $\quad$ The Present Progressive}

The present progressive is used to refer to things or actions which happen over a limited period in the current/ present time, which, in the view of Bybee et al (1994), applies mainly to dynamic predicates and not to stative ones as in the following examples:

They are staying in a hotel nowadays.

He is kicking the ball. 
- The Past Progressive

The past progressive is used to describe ongoing events or actions that were in progress at a point of time in the past. Similar to the present progressive, it is used with dynamic predicates, but not with stative ones. It is normal that the conjunction while is used before the past progressive and when before the simple past. It must be added that the two conjunctions while and when can be substituted.

The children were watching $T V$ when their father suddenly came.

While she was cooking, the electricity suddenly went off.

- $\quad$ The Present Perfect

The present perfect is used when an action happened in the past, but it is related to the present. Clearly, it is used for events or actions that continue up to the moment of speaking, or ended just a short time before the time of speaking and it is still important. Greenbaum and Quirk (1990: 51) point out that "The present perfect is used to refer to a situation set at some indefinite time within a period beginning in the past and leading up to the present." Examples of this can be as follows:

He has broken the window. $\quad$ (The window is still broken as seen by others.)

I have not visited Italy. $\quad$ (I do not know how it is.)

It has been noted by Al-Buainain (1992) that a great deal of attempts has been made to establish a unitary meaning for the English perfect, and as far as its use is concerned, it can be used to indicate an action completed in the past, but whose result or outcome is still in effect and/ or whose effects are still relevant.

\section{- $\quad$ The Past Perfect}

The past perfect is used to describe two actions, both of which happened in the past, but one of them happened before the other, and thus, the two actions are expressed by means of using different verb forms. It is used when an action happened in the past and continued to a point of time in the past. Greenbaum and Quirk (1990:53) clarify that the past perfect is used to refer to "a time earlier than another past time", adding that "it may represent the past of the simple past, a time earlier than that indicated by the simple past. Examples of this can be as follows:

They had been in the room for an hour when the manager arrived.

He had written a book before he got married.

\section{Research Methods and Procedures}

\subsection{Research Instrument/Tool}

The research instruments used for the purpose of this research are a test and a questionnaire. Both instruments were used so that an explicit picture of the issue investigated can be obtained in such a way that the more instruments used, the more the point investigated is clearer (Babbie 1995, Best and Khan 1995 and Wallace 2004). Both instruments were given to the students, who are the sample members of this research.

The test is composed of twenty four items presented in sentences in the way that there are two tenses (the present and past simple), four aspects (two progressive and/ or continuous (the present and past), and two perfective (the present and past) leading to six areas; and for each one four items were given to test those learner's ability to use the tense and aspect correctly. There was also another section composed of a short text, including sentences to test such learners' ability in handling the use of tense and aspect in connected language. It must be stated that the items of the test administered to the students of this study were not written in order. In other words, the four items allocated to each of the tenses and aspects were not written in succession; one after the other, but they were jumbled so that the respondents of the research would not deal with it in a mechanical manner, which may have a negative effect on their answers. (See the test in Appendix A.) Briefly, the researcher's goal is to see whether such respondents would do better, worse, or similar in the separated sentences and the connected ones. Regarding the use of the questionnaire, it is meant that such an instrument is used to solicit the learners' opinions on the level of difficulty and/ or complexity that such learners encounter in the use of tense and aspect. To that Nunan (1992), states that a questionnaire is a very common and reliable means of collecting data. It has two sections; the first includes Yes/ No questions, and the second section includes questions with three options for answering. All the questions of the questionnaire are focused on the present and past simple, present and past progressive, and present and past perfect. (See Appendix B.) The English version of the questionnaire was translated into Arabic for the purpose of facilitating comprehension on the part of the respondents. (See Appendix C.)

Both instruments were validated to check face and content validity using the judges' method. They were also tried out on about more than the third of the research respondents of the research in order to check how long they would take in answering the instruments' items, and how they would react to the different items of both instruments. All such procedures were taken before the final administration of the instruments on the meant research sample members. 
The sample of the research included 58 members of students nearing graduation in the College of Engineering, University of Jazan in the academic year 2013- 2014 corresponding to 1434 - 1435 Hijri. It must be noted here that the terms research sample members, research respondents and learners of this study are to be used synonymously all through this research. It must be added that those students have studied quite a good amount of English at their university learning in the way that they study a course in the preparatory year, which is somehow introductory and general. Then they study a course of ESP English, which is mostly technical so as to be suitable for their specific study of Engineering. In this final year, they study a concluding course of English, which is supposed to help them prepare for a graduation project and also give them some aid for their future careers and professional development.

\section{Results and Discussion}

The research is intended to identify, categorize and analyze the errors made by the learners taken as the sample members investigated for the purpose of this research. For that purpose, a test and a questionnaire were introduced to this group. Regarding the statistical tools used to arrive at such results, percentages were used. The analysis is supported by tables including numbers of frequencies of correct and incorrect use of tense and aspect in the case of the test administered on the respondents of the study; and also numbers requiring Yes/ No answers in the case of the questionnaire administered on the same group. Clearly, the respondents' replies to the different test items are presented in the tables given in this section. First, an analysis of how the respondents reacted to the test items is given in one section, which is divided into $\mathrm{A}$ and $\mathrm{B}$ in the way that in $\mathrm{A}$, there is a discussion of how those respondents treated the test items when used in isolated sentences, and in B the discussion focuses on how they treated such items when used in a paragraph. Further, section two is dedicated to discussing the learners' respondents to the items of the questionnaire.

\section{Section I}

A: The information presented in table (1) includes the data of the first section of the test comprising a number of items that are meant to test the use of the English tense and aspect by the learners investigated for the purpose of this research.

Table 1. The frequencies and percentages of the correct and incorrect use of the categories included in section I

\begin{tabular}{lllll}
\hline Category-Tested & Correct & Percentage & Incorrect & Percentage \\
\hline Simple Present & 129 & $56 \%$ & 103 & $44 \%$ \\
\hline Simple Past & 125 & $54 \%$ & 107 & $46 \%$ \\
\hline Present Progressive & 120 & $52 \%$ & 112 & $48 \%$ \\
\hline Past Progressive & 119 & $51 \%$ & 113 & $49 \%$ \\
\hline Present Perfect & 108 & $47 \%$ & 124 & 53 \\
\hline Past Perfect & 100 & $43 \%$ & 132 & $57 \%$ \\
\hline
\end{tabular}

The respondents' treatment of the first tense tested, which is the simple present, is given as (56\%) correct and (44\%) incorrect, which indicates that such respondents made a correct use of it but at an acceptable level. Regarding the use of the simple past, the statistical figures tell us that they got it correct to some extent $(54 \%)$, whereas their incorrect use was not that large $(46 \%)$.

Dealing with the use of the present continuous and/ or progressive, the numerical data in the table above show that they used it correctly to a certain extent $(52 \%)$, while those using it incorrectly were $(48 \%)$. In relation to their use of the past continuous and/ or progressive, it is seen that they also used it correctly to an acceptable degree being (51\%), but those using it incorrectly were at quite a lower degree being (49\%).

Reacting to the present perfect, it is clear that they got it incorrect to quite a considerable extent (52\%), when those who got it correct were somehow low (48\%). As for their use of the past perfect, the numerical data indicate that those who used it correctly were lower (43\%) than those who used it correctly (57\%).

B: As far as their use of tense and aspect in a connected piece of language; a paragraph, the respondents' treatment of the items expressing such a grammatical area is given in the table and details below. It is worth pointing that the uses of tense and aspect given in the paragraph were presented naturally, which means tense and aspect items were jumbled.

Table 2. The frequencies \& percentages of the correct and incorrect use of tense and aspect items used in the paragraph

\begin{tabular}{lllll}
\hline Category-Tested & Correct & Percentage & Incorrect & Percentage \\
\hline Present Progressive & 12 & $21 \%$ & 46 & $79 \%$ \\
\hline Present Perfec & 22 & $38 \%$ & 36 & $62 \%$ \\
\hline Past Progressive & 26 & $45 \%$ & 32 & $55 \%$ \\
\hline Simple Past & 27 & $47 \%$ & 31 & $53 \%$ \\
\hline Past Perfect & 10 & $17 \%$ & 48 & $83 \%$ \\
\hline Present Simple & 28 & $48 \%$ & 30 & $52 \%$ \\
\hline
\end{tabular}


The first blank in the paragraph requires the use of the present progressive; and it is very obvious from the numerical data that they deviated from the correct use of this aspect to a very large extent (79\%), while those who used it correctly were just (21\%). As for the use of the present perfect that is required in the second blank, the statistical figures say that they also went largely wrong in its use as those who used it incorrectly were $(62 \%)$, but those who used it correctly were only (38\%). Looking at their responses to the past progressive, it is shown that the ones who used it correctly were of a lower number $(45 \%)$ than those who used it incorrectly $(55 \%)$.

In using the simple past, it is seen in the table that the correct use of such a tense was a little lower (47\%) than the incorrect use $(53 \%)$. The respondents dealt with the use of the past perfect in the way that those who used it correctly were very low $(17 \%)$, whereas those who used it incorrectly were largely many ( $83 \%)$. Examining the use of the simple present, the numerical data in the table tell us that their correct use of such a tense was quite lower (48\%) than their correct use which was $(52 \%)$.

\subsection{Implications of the Results Obtained by the Test}

To establish a link between the questions of the research and the results discussed in these two sections, it is of concern to refer to the first question that was focused on how common are the errors made by the sample members in the use of tense and aspect. This question also tried to find which grammatical category of tense or aspect was more complex than the other.

Looking carefully into this analysis of the results, it is obvious that the learners included in this study are still away from the right track as far as the use of tense and aspect is concerned. However, variation is there as it is seen that such learners seem to be more familiar with the use of the simple present, and the simple past tenses as the percentages of their correct use support this $(56 \%)$ and $(59 \%)$ respectively. Their uses of the present and past continuous/ progressive are quite acceptable, being (53\%) and (51\%) respectively. These results imply that those learners are having some difficulty in these uses up to the levels shown above. The explanation that can be made regarding these results is that since such learners had a certain amount of English learning in their pre-university education, and also in their university education, this had possibly facilitated their task in using these tenses in addition to quite a lesser ability of using the present and past progressive aspects.

Nevertheless, the complexity arises when it comes to their use of the present perfect and past perfect aspects. The results achieved by such learners in the two aspects suggest that they are still having a great deal of complexity in such uses as their correct uses were $(48 \%)$ and $(45 \%)$ respectively. Such a complexity can be attributable to some reasons such as unsuitable learning materials, improper teaching methods used by some incompetent teachers, and possibly low motivation on the part of a large number of learners.

As far as the question pertinent to whether the complexity is larger in the use of tense or the use of aspect, it can be inferred from the statistical information in the table below that the use of aspect is quite more complex than the use of tense. However, this complexity is not that remarkable as they got the correct use of the tenses (55\%) compared to the correct use of the aspects as $(48 \%)$.

Table 3. The frequencies and percentages of all the correct and incorrect uses of tense and aspect

\begin{tabular}{|c|c|c|c|c|}
\hline & \multicolumn{4}{|c|}{ The Two Categories of Tenses \& Aspects (Compared) } \\
\hline & Tenses & & Aspe & \\
\hline & No. & $\%$ & No. & $\%$ \\
\hline Correct & 254 & 55 & 447 & 48 \\
\hline Incorrect & 210 & 45 & 481 & 52 \\
\hline Total & 464 & 100 & 928 & 100 \\
\hline
\end{tabular}

The question concerning whether such learners find it more complex to use tense and aspect in isolated sentences and/ or in sentences that are connected; a paragraph, the numerical data in the summary table below answer this question.

Table 4. The extent of complexity in the use of tense and aspect in isolated sentences and connected ones

\begin{tabular}{lllllllll}
\hline & \multicolumn{3}{l}{$\begin{array}{l}\text { Tense \& Aspect (in the isolated } \\
\text { sentences) }\end{array}$} & \multicolumn{5}{l}{$\begin{array}{l}\text { Tense \& Aspect (in the connected } \\
\text { sentences) }\end{array}$} \\
\cline { 2 - 11 } & Correct & \multicolumn{1}{l}{ Incorrect } & \multicolumn{2}{l}{ Correct } & Incorrect \\
\hline Simple Present & No. & $\%$ & No. & $\%$ & No. & $\%$ & No. & $\%$ \\
\hline Simple Past & 129 & 56 & 103 & 44 & 28 & 48 & 30 & 52 \\
\hline Present Progressive & 125 & 54 & 107 & 46 & 27 & 47 & 31 & 53 \\
\hline Past Progressive & 120 & 52 & 112 & 48 & 12 & 21 & 46 & 79 \\
\hline Present Perfect & 119 & 51 & 113 & 49 & 26 & 45 & 32 & 55 \\
\hline Past Perfect & 108 & 47 & 124 & 53 & 22 & 38 & 36 & 62 \\
\hline Total & 100 & 43 & 132 & 57 & 10 & 17 & 48 & 83 \\
\hline
\end{tabular}


The figures clearly show that those learners encounter a greater complexity in the use of tense and aspect in sentences that are written in connection, a paragraph, while this complexity is not that sharp in the case of using tense and aspect in isolated sentences. The inference made is that such learners have received most of their learning of the uses of tense and aspect in isolated sentences. This is supported by the percentages obtained by those respondents being (36) in the correct use and (64) in the incorrect use.

\section{Section Two}

The analysis here is attempted on the respondents' reactions to the questions included in the questionnaire, which was divided into two sections; the first section was dedicated to questions on whether such respondents find it complex to use the tenses and aspects investigated in this research. And each question of those included in this section was clarified by three options indicating the degree of complexity, such as very complex, just complex, and moderately complex.

To analyze the first section, the data obtained from the sample members of the research are presented in the table below.

Table 5. The complexity level of tense and aspect

\begin{tabular}{|c|c|c|c|c|c|c|c|c|c|}
\hline \multirow{2}{*}{$\begin{array}{l}\text { Category } \\
\text { Simple Present }\end{array}$} & \multirow[b]{2}{*}{ Yes } & \multirow{2}{*}{$\begin{array}{l}\text { Frequency } \\
24\end{array}$} & \multirow{2}{*}{$\begin{array}{l}\% \\
41\end{array}$} & \multicolumn{2}{|c|}{$\begin{array}{l}\text { Very } \\
\text { Complex }\end{array}$} & \multicolumn{2}{|c|}{ Just Complex } & \multicolumn{2}{|c|}{$\begin{array}{l}\text { Moderately } \\
\text { Complex }\end{array}$} \\
\hline & & & & 16 & $28 \%$ & 20 & $34 \%$ & 22 & $38 \%$ \\
\hline & No & 34 & 59 & & & & & & \\
\hline \multirow[t]{2}{*}{ Simple Past } & Yes & 23 & 40 & 15 & $26 \%$ & 13 & $22 \%$ & 30 & $52 \%$ \\
\hline & No & 35 & 60 & & & & & & \\
\hline \multirow{2}{*}{$\begin{array}{l}\text { Present } \\
\text { Progressive }\end{array}$} & Yes & 41 & 71 & 38 & $66 \%$ & 11 & $19 \%$ & 9 & $15 \%$ \\
\hline & No & 17 & 29 & & & & & & \\
\hline \multirow[t]{2}{*}{ Past Progressive } & Yes & 43 & 74 & 36 & $62 \%$ & 15 & $26 \%$ & 7 & $12 \%$ \\
\hline & No & 15 & 26 & & & & & & \\
\hline \multirow[t]{2}{*}{ Present Perfect } & Yes & 40 & 69 & 39 & $67 \%$ & 12 & $21 \%$ & 7 & $12 \%$ \\
\hline & No & 18 & 31 & & & & & & \\
\hline \multirow[t]{2}{*}{ Past perfect } & Yes & 44 & 76 & 40 & $69 \%$ & 16 & $28 \%$ & 2 & $3 \%$ \\
\hline & No & 14 & 24 & & & & & & \\
\hline
\end{tabular}

The figures in table (5) tell that the respondents do not seem to perceive a considerable degree of complexity in the use of the simple present tense (41\%) compared with their good reaction that such a tense does not represent a considerable complexity denying this complexity to a good extent (59\%). In response to the extent of complexity in the use of this tense, it is shown that it is not that complex, and the choice of moderately difficult got the highest percentage being (38). Examining the responses given on the complexity in the use of the simple past and to what extent is that complexity is, it is noticed that they believe that it does not form a considerable degree of complexity as they denied this complexity at $(60 \%)$ while those realizing such a complexity were less being $(40 \%)$. Regarding the level of complexity felt by such learners in using this tense, it is fluctuating between very difficult $((26 \%)$, and just difficult $(22 \%)$, whereas the larger number indicated that it is being moderately difficult (52\%).

The figures in this table also show that those learners have a great deal of complexity in the use of the present continuous and/ or progressive aspect as being accepted as difficult at the percentage of (71). However, those denying such a complexity are much less (29\%). Regarding the extent of complexity encountered by such respondents, it is clear that they largely feel that it is difficult to use this aspect as the results tell that (66\%) view it as very difficult.

The numerical data regarding the respondents' reaction to whether they think that the past continuous/ progressive aspect is difficult or not; it is seen that they even find it more complex (74\%) than the present progressive. And in relation to the degree of complexity felt by such respondents, it is of quite a large degree as indicated by those selecting the very complex option (62\%). The statistical information concerning the opinion of the respondents on the use of the present perfect, it is noticed in the table that this aspect is also perceived as largely difficult (69\%), when the degree of this complexity is also largely considerable $(67 \%)$ as very difficult. Quite higher than the respondents' reaction to the use of the present perfect, their reaction to whether the use of the past perfect is complex or not, it is shown that it is considerably of a larger degree of complexity (76\%). At the same time, the extent of such a difficulty is very large $(69 \%)$. 
Table 6 . The complexity of tense and aspect when used in the two skills of reading \& writing

\begin{tabular}{lllll}
\hline Category & Reading & \multicolumn{3}{l}{ Writing } \\
\cline { 2 - 5 } & Yes & No & Yes & No \\
\hline Simple Present & $22(38 \%)$ & $36(62 \%)$ & $23(40 \%)$ & $35(60 \%)$ \\
\hline Simple Past & $20(34 \%)$ & $38(66 \%)$ & $28(48 \%)$ & $30(52 \%)$ \\
& & & & \\
\hline Present Continuous/ Progressive & $27(47 \%)$ & $31(53 \%)$ & $34(59 \%)$ & $24(41 \%)$ \\
\hline Past Continuous/ Progressive & & & \\
& $26(45 \%)$ & $32(55 \%)$ & $39(67 \%)$ & $19(33 \%)$ \\
\hline Present Perfect & & & & $17(29 \%)$ \\
\hline Past Perfect & $31(53 \%)$ & $27(47 \%)$ & $41(71 \%)$ & $12(21 \%)$
\end{tabular}

This section analyzes the questions given to the sample members on whether they see that it is difficult to use tense and aspect in the case of the two skills of reading and writing.

The results obtained and presented in table (6) indicate that this complexity is of a lower degree in the case of reading than it is in the case of writing. To go into more details, the figures show that those learners get well with the use of the simple present and simple past tenses as well as the present and past progressive aspects particularly in the reading skill. The results suggest that it is only (38\%) difficult for them to get familiar with the simple present in reading, whereas it is also only (40\%) complex to use this tense when writing. Meantime, the simple past is also just (34\%) complex to get familiar with in reading, and it is just (48\%) complex to use in writing. Further, the indication of such a result tells us that such learners have to read materials in English and also write reports and other writings in English, therefore, their ability to recognize tense and aspect, mainly, the ones tested in this research, is of great importance.

It is clear that the present continuous/ progressive is just normal for such learners when they read (47\%), but it is relatively more difficult than the simple present and simple past when they write $(59 \%)$. The past progressive is difficult to some extent when such learners read $(45 \%)$, but it is largely complex $(67 \%)$ when they write. The present is perfect, however, is greatly difficult in both skills in the way that those respondents agree that it is complex to the extent of $(53 \%)$ when they read, and $(71 \%)$ when they write. Addressing their opinion on the complexity of the past perfect, it is seen as being difficult for them to read (57\%) and also greatly complex to write (79\%).

\section{Conclusions Gathered from Discussing the Test \& the Questionnaire}

The research posits a number of questions that have been answered in the discussion attempted earlier, and depending on such a discussion, the following conclusions can be made.

1. It can be gathered that the real problem of the respondents of this study is that they find it a hard task when they attempt to recall the rules of this area of grammar in order to use these tenses and aspects correctly. It is a hard task mentally that they have to think and rethink about such rules, which in turn, has its influence on their learning as a whole. Meantime, they have to revise these rules every now and then, otherwise, they are likely to forget them.

2. Those learners like almost other EFL learners in similar learning settings encounter a great deal of complexity in their learning and use of tense and aspect. This is clearly observed, particularly in the case of the use of the progressive and the perfective aspects in English.

3. The number of errors ascribed to the learners' unfamiliarity with the English aspects is greater than the number of errors ascribed to their low level of mastery of the English tenses. Thus, the English aspect is a greater cause of complexity to such learners than the English tense.

4. The students, taken as the respondents of this research, seem unclear about such uses which were not possibly made clear to them at the earlier stages of learning on how to use tense and aspect. This can be supported by the fact that they had studied English for six years before joining the university, and also they have learnt English for almost two or more years in addition to their learning of English in their specialist courses. However, their level is still below expectation.

5. The Present and Past simple tenses are given more learning and possibly additional practice than the Progressive and Perfective aspects, which happened in the two stages of learning, i.e., the pre-university stage and the university stage.

\subsection{Recommendations}

\subsubsection{Recommendation for the Educational Authorities}

1. Educational authorities are required to give priority to this very important component of the English language grammar; teaching English can never do without teaching grammar.

2. Such authorities are urged to provide the teachers of English, mainly at the stages before the university, with adequate training on how to deal with grammar points like this one. In such a training, the learning areas that are of greater complexity to learners should be given a longer span of time and a greater deal of effort. 
5.1.2 Recommendations for Curricula Designers/ Developers

1. Curricula designers and developers are supposed to build the teaching materials in the courses offered to learners like the ones of this study in such a way that they consider the differences between the two languages in the areas of tense and aspect, paying greater attention to the progressive and perfective aspects.

2. They are required to enrich the learning materials designed for their learners with sufficient drills and exercises so that teachers can make use of such drills and exercises so as to give learners adequate chances to practice what they learn.

3. They should provide the learning materials with hints that can aid teachers of how to tackle problems of differences between the target language and the learners' mother tongue.

4. They should present the learning materials in a logical order considering the level of complexity of each tense and aspect.

5. The learning content designed has to be introduced through a sufficient comprehensible input in the way that the daily life of learners is represented in a way or another so that some kind of connection between the learners' daily life and their learning can be established.

\subsubsection{Recommendations for Teachers}

1. Teachers are supposed to build their teaching to those learners in a way that the areas of greater complexity should be given extra attention and care. To do that effectively, learners should be drilled on the rules of tense and aspect so that such learners can have a clear understanding of the difficulties that they encounter when it comes to use.

2. Teachers should try their best to clarify as much as possible the problems that may result from differences between the language learnt and the learners' mother tongue.

3. Teaching, from time to time, should be linked to students' daily life situations. For example, the students can be drilled on writing sentences about their daily routines so that the simple present can be well learnt. In the case of the simple past, teachers can make use of some historical events and facts that happened in the past as well as activities that were made by students during summer vacations. In the case of the other aspects such as the present progressive, past progressive, present perfect, past perfect teachers can make use of a number of activities that cannot be listed here because they are many. Such drills and activities are discussed and presented in different grammar textbooks.

4. Practice of comparison and contrast is definitely an effective measure giving students a clear way of such uses. Further, it helps learners differentiate and remember easily and quickly such rules.

5. When correcting errors made by learners, these errors must be corrected in the manner that they should not be treated as something bad on the part of learners, but rather as attempted strategies to arrive at the correct use of a rule.

\section{References}

Abbad, A. (1988). An Analysis of Communicative Competence Features in English Texts in Yemen Arab Republic, PhD. Dissertation. Illinois University at Urbana: USA.

Al-Buainain, H. A. (1992). Present Progressive: Suggestions for Teaching this Form to Arab Students of ESL. IRAL, 20 (4), 109-126.

Al-Faleg, O. (1991). A Comparison of Morpheme Acquisition Order in Learners of English as a Second Language: The Case of Adult Learners in Saudi Arabia, Unpublished M.A. Thesis. Indiana University: USA.

Al-Fallay, I. (1998). English Tenses and Aspects: Are they too Difficult for Arab Students to Master, Abhath-AlYarmouk: Humanity \& Social Sciences, 15 (4), 9 - 29.

Al-Mutawa, N., and Kailani, T. (1998). Methods of Teaching English to Arab Students. Longman Group Limited: England.

Al-Quyadi, A. M. (1996). Errors in the Use of Articles: A Case Study of the First and Fourth Level Students in the Department of English, Faculty of Education, Unpublished M.A. Thesis. Sana'a University, Sana'a: Yemen.

Babbie, E. (1995). The Practice of Social Research. Wordsworth Publication Co.: California.

Basaeed, E. (2013). An Approach fo Teaching English Language Grammar to Arab Young Learners, IOSR Journal of Research and Method in Education (IOSR - JRME), 1 (2), 20 - 30. Retrieved from: http://www.iosrjournals.org/iosrjrme/papers/Vol-1\%20Issue-2/E0122030.

Best, J. and Khan, J. (1995). Research Methods in Education. Bhavan Publications: New Delhi.

Broughton, G. , Brumfit, C. , Flavell, R. , Hill, P. , Pincas, A. (1996). Teaching English as a Foreign Language. Routledge, Kentucky: USA.

Brown, D. (1994). Principles of Language Learning and Teaching. Prentice Hall Regents: New Jersey.

Bybee, J., Perkins, R. and Pagliuca, W. (1994). The Evolution of Grammar: Tense, Aspect, and Modality in Languages of the World. The University of Chicago Press: Chicago.

CelceMurcia, M. (Ed.) (1991). Teaching English as a Second or Foreign Language. Newbury House: New York. (1991). Grammar Pedagogy in Second and Foreign Language Teaching. TESOL Quarterly, 15 (3), $459-480$.

Chalker, S. (1992). Current English Grammar. Macmillan Ltd.: London. 
Cook, V. (2001). Second Language Learning and Teaching. Edward Arnold: New York.

Davison, J. and Moss, J. (2000). Issues in English Teaching. Routledge: London.

DeCapua, A. (2008). Grammar for Teachers: A Guide to American English for Native and Non-Native Speakers. Springer: New York.

Doughty, C. \& Williams, J. (1998). Focus on Form in Classroom Second Language Acquisition. CUP: Cambridge.

Dubin, F. and Olhatain, E. (1991). Course Design: Developing Programs and Materials for Language Learning. CUP: Cambridge.

Dulay, H., Burt, M. and Krashen, S. (1988). Language Two. OUP: Oxford.

Ebsworth, M. \& Schweers, C. (1997). What Researchers Say and Practitioners Do: perspectives on conscious grammar instruction in the ESL classroom, Applied Language Learning, 8 (2), 205-228.

Ellis, R. (1994). The Study of Second Language Acquisition. OUP: Oxford.

Gebhard, J. (2009). Teaching English as a Foreign or Second Language: a self-development and methodology guide. Michigan University Press: Michigan.

Greenbaum, S. and Quirk, R. (1990). A Student's Grammar of the English Language. Longman Group Ltd: London.

Harmer, J. (1997). The Practice of English Language Teaching. Longman: London.

Hedge, T. (2000). Teaching and Learning in the Language Classroom. OUP: Oxford.

Hornby, A. S. (1999). Guide to Pattern and Usage in English. OUP: Oxford.

James, C. (1998). Errors in Language Learning and Use. Longman: London.

Jdetawy, L. F. (2011). Problems Encountered by Arab EFL Learners, Language in India: Strength for Today and Bright Hope for Tomorrow, 11, 1-12.

Khan, I. (2012). Teaching and Learning of English: An Exploratory Study of Difficulties and Strategies. Retrieved from: www.bjss.baar-org: UK, 1 (1), $76-93$.

Leech, G. and Svartvik, J. (1984). A Communicative Grammar of English. Longman: London.

Littlewood, W. (1992). Foreign and Second Language Learning: Language Acquisition Research and its Implications for the Classroom. CUP: Cambridge.

Mukattash, L. (1983). The Problem of Difficulty in Foreign Language Learning, in: Dahiyat, E. and Ibrahim, M. (Eds.). Papers from the First Conference on the Problems of Teaching English Language and Literature at Arab Universities. Amman University: Jordan.

Norrish, J. (1983). Language Learners and their Errors. Basingstoke: London.

Nunan, D. (1992). Research Methods in Language Learning. CUP: Cambridge.

Nunan, D.(1999). Language Teaching Methodology. Prentice Hall International Ltd.: UK.

Oxford, R. (1990). Language Teaching Strategies: what every teacher should know. Newbury House: New York.

Rababah, G. (2005) Communication Problems Facing Arab Learners of English, Journal of Language and Learning, 3 (1), 1740-1767.

Rutherford, W. \& SharwoodSmith, M. (1988). Grammar and Second Language Teaching. New York: Newbury House. Sahu, R. (1999). To Greater Heights: Improving English Language Competence of Yemeni Learners. Retrieved from: http://www. Yemen Times. com. Yemen Times: Weekly Newspaper. Issue Vol. IX, 5, p. 9.

Suleiman, S. (1983). Teaching English to Arab Students at University Level' in: Dahiyat, E. and Ibrahim, M. (Eds.) Papers from the First Conference on the Problems of Teaching English Language and Literature at Arab Universities. Amman University: Jordan.

Swan, H. (1987). Practical English Usage. OUP: Oxford.

Telda, Y. \& Desta, M. (2014). Reading Stories to Enhance English Grammar Intake: Correlational Analysis, International Journal of English language \& Translation Studies, Vol. 2 (1), 92 - 105.

Thakur, D. (1987). A Handbook of English Grammar and Usage. Bharat Bavan: New Delhi.

Thornbury, S. (1999). How to Teach Grammar. Longman: Essex.

Wallace, M. (2004). Action Research for Language Teachers. CUP: Cambridge.

Yule, G. (2000). Explaining Grammar. OUP: Oxford. 
Dear student,

Appendix A

This test is a part of a research that is conducted for the purpose of finding out the difficulties and/ or complexities that you encounter in the use of the English tense and aspect. Kindly answer the test items as correctly and honestly as possible.

Thanking you

Section 1: Kindly read each item carefully, and answer it as correctly as possible.

A: Encircle the correct verb/ choice.

1. Tareq

to France last summer.

2. Don't go out. It

goes

b. went

c. go

3. Bob usually outside.
a. is raining
b. rains
c. rain

4. They a sandwich for lunch.
a. eat
b. ate
c. eats

5. to this city four weeks ago
a. come
b. comesc. came you a student?

6. The students
c. Is
b. Do
a. Are

English now.
a. learn
b. learns c. are learning

7. Mohammed many games at the age of 15 .
a. played
b. plays c. play

8. While the teacher on the board, Moneer raised his hand.
a. writes
b. write c. was writing

9. $\mathrm{We}$ home at 10 o'clock yesterday.
a. arrive
b. arrived
c. arrives

10. The light suddenly went off while they TV.
a. watches
b. watch c. were watching

11. Huda English since she was six
a. learns
b. learn
c. has learnt

12. He knew later that he the door.

a. hadn't locked b. doesn't lock c. isn't locking

13. My father and mother two cups of coffee every morning.
a. had
b. have
c. had

14. Faris speaks Arabic, but right now, he English.
a. is speaking
b. speaks
c. speak

15. We TV at the moment.
a. watch
b. watches
c. are watching

16. The students in the classroom for 50 minutes.

a. have stayed b. stays c. stay

17. Our class usually at ten every Monday.
a. starts
b. start
c. started

18. On arriving at the airport, the plane
a. leave
b. leaves c. had left

19. His brother his wallet.
a. lose
b. is losing
c. has lost

20. All the family love their house very much because they
a. have lived
b. live

in it all their life.

21. By the time they got to the office, the manager
a. had left
b. leaves
c. leave 

the test.
a. fails
b. fail
c. had failed

23. Sami his homework when his friend visited him.
a. does
b. was doing
c. did

24. While he , the phone rang.
a. sleep
b. sleeps
c. was sleeping

\section{Section 2: Read this little text and underline the correct verb/choice between brackets.}

- I am glad to hear that you here are as usual. Your father while he come) to h (works/was working/work), many of our neighbors (enjoys/ enjoy/ are enjoying) yourself in Australia these days. Things (finish/ has finished/finishes) the work in the garden. Last week prepare/ doesn't preparel hadn't prepared) well for it. The whole family will be glad to know what you (does/ did/ do) every day.

\section{The Questionnaire (the English Version)}

\section{Appendix B}

Questionnaire on the Difficulties and/ or Conmplexities Encountered by EFL Learners in the Use of the English Tense and Aspect

Dear student,

This questionnaire includes questions on the difficulties and/ or complexities that EFL learners of English encounter in the use of the present simple and past simple tenses. The questionnaire also includes some other questions on the difficulties and/ or complexities that the same learners encounter in the use of the present, past continuous and/ or progressive, and the present and past perfect aspects. The questions are given below. You are kindly requested to answer the questions completely and correctly. The answers given will be used only for the research purposes and not for any other purposes.

\section{Section One: Please tick ( ) the correct choice/ answer.}

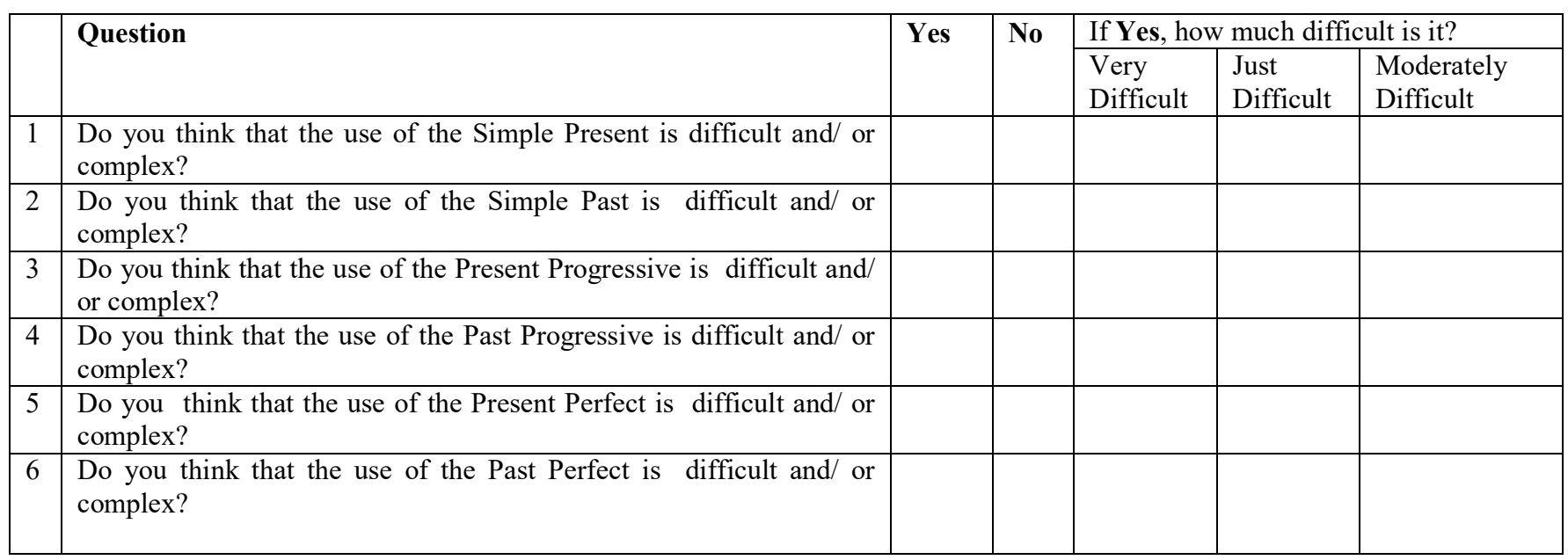

\section{Section Two: Please tick () the correct choice/ answer.}

Q1: In which skill or activity do you find it difficult and/ or complex when using the present simple tense? Is it, for example, in?

$$
\text { Reading O Yes O No, Writing O Yes O No }
$$

Q2: In which skill or activity do you find it difficult and/ or complex when using the past simple tense? Is it, for example, in?

\section{Reading O Yes O No, Writing O Yes O No}

Q3: In which skill or activity do you find it difficult and/ or complex when using the present continuous and/ or progressive aspects? Is it, for example, in?

$$
\text { Reading O Yes O No, Writing O Yes O No }
$$

Q4: In which skill or activity do you find it difficult and/ or complex when using the past continuous and/ or progressive aspects? Is it, for example, in?"

$$
\text { Reading O Yes O No, Writing O Yes O No }
$$


Q5: In which skill or activity do you find it difficult and/ or complex when using the present perfect? Is it, for example, in?

\section{Reading O Yes O No, in Writing O Yes O No}

Q6: In which skill or activity do you find it difficult and/ or complex when using the past perfect? Is it, for example, in? Reading O Yes O No,

Writing O Yes O No

\section{Appendix C}

استبانة

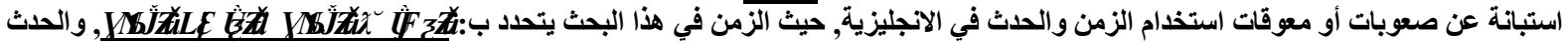

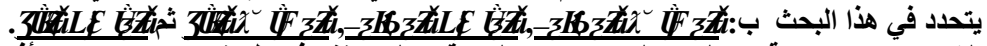

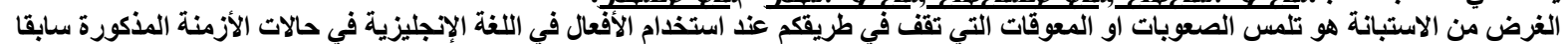

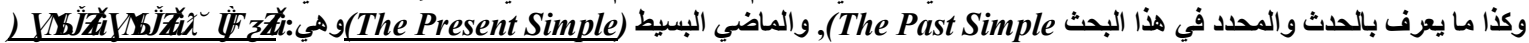

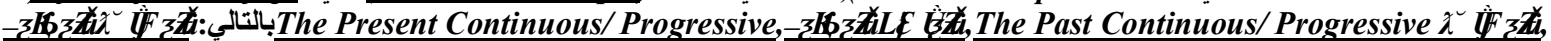

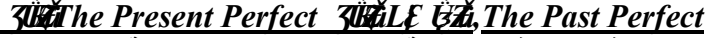

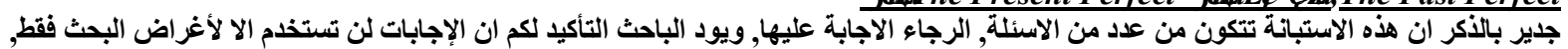
وليس لأي غرض اخر. امثلة على الاستخدامات التي تنتاولها الاستبانة:

Mohammed goes to school every day. Mohammed went to school yesterday. الماضي البسيط البطر - -

Mohammed is learning English now. المضار ع المستمر Mohammed was doing his work last night. الماضي المستمر المسنتر Mohammed has finished his work. المضارع التبنر -

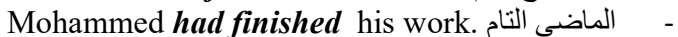
القسم الاول: الرجاء وضع علامة (/) في الحقل الذي يدل على اختيارك الصحيح.

\begin{tabular}{|c|c|c|c|c|c|c|}
\hline & & درجة الصعوبة & لا & ن اعم & \multicolumn{2}{|c|}{ العبارة او الجملة } \\
\hline صدرجة أقل مربك & مربك او & صعب او مربك جدا & & & & \\
\hline & & & & & هل تجد أن استخدام المضار ع البسبط صعبا أو مربكا؟ & 1 \\
\hline & & & & & هل تجد أن استخدام الماضي البسيط صعبا أو مربكا؟ & 2 \\
\hline & & & & & هل تجد أن استخدام المضار ع المستمر صعبا أو مربكا؟ & 3 \\
\hline & & & & & هل تجد أن استخدام الماضي المستمر صعبا أو مربكا؟ & 4 \\
\hline & & & & & هل تجد أن استخدام المضار ع التام صعبا أو مربكا؟ & 5 \\
\hline & & & & & هل تجد أن استخدام الماضي التام صعبا أو مربكا؟ & 6 \\
\hline
\end{tabular}

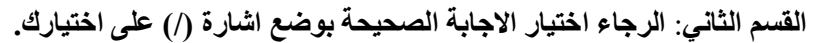

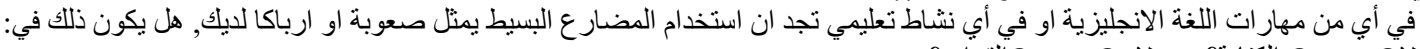

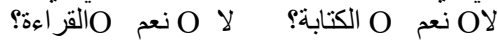
2. في أي من مهار ات اللغة الانجليزية او في أي نشاط نعليمي تجد ان استخدام الماضي البسيط يمثل صعوبة او ارباكا لايك, هل يكون ذلك في:

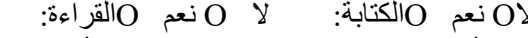
في أي من مهار ات اللغة الانجليزية او في أي نشاط نعليمي تجد ان استخدام المضار ع المستمر يمثل صعوبة او ارباكا لايك, هل يكون ذلك في:

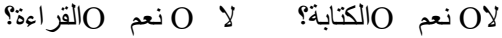
في أي من مهار ات اللغة الانجليزية او في أي نشاط تعليمي تجد ان استخدام الماض المستمر يمثل صعوبة او ارباكا لديك, هل يكون ذلك في:

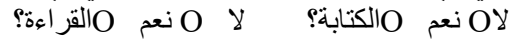
في أي من مهار ات اللغة الانجليزية او في أي نشاط تعليمي تجد ان استخدام المضار ع التام يمثل صعوبة او ارباكا لديك, هل يكون ذلك في:

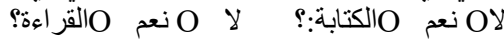
في أي من مهار ات اللغة الانجليزية او في أبي نشاط تعليمي تجد ان استخدام الماضي التام يمثل صعوبة او ارباكا لايكك, هل يكون ذلك في:

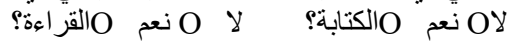

